\title{
The Perception of Film Attractiveness and Its Effect on the Audience Satisfaction, Intention and Investment
}

\author{
Dongjin Yang, Xueying Zhong \\ Management School, Jinan University, Guangzhou, China \\ Email: yang.dongjin@163.com
}

Received 28 December 2015; accepted 2 February 2016; published 5 February 2016

Copyright (C) 2016 by authors and Scientific Research Publishing Inc.

This work is licensed under the Creative Commons Attribution International License (CC BY). http://creativecommons.org/licenses/by/4.0/

(c) (i) Open Access

\begin{abstract}
This article adopts empirical research methods to measure the content of Chinese film attractiveness. Exploratory and confirmatory factor analysis is used to extract and verify 5 dimensions: moral education, plot, satisfaction of curiosity, entertainment and reputation. Then it analyzes the effect of the perception of film attractiveness on the audience satisfaction, intention, investment and the mediating effect of satisfaction. The findings demonstrate that: 1) satisfaction mediates film attractiveness and intention, and it also mediates film attractiveness and investment; 2) the path of film attractiveness affects audience is: perception of film attractiveness $\rightarrow$ satisfaction $\rightarrow$ intention $\rightarrow$ investment; and 3) mind purification, logic and inspiration are main factors to improve satisfaction. Overall, this research provides insightful theoretical and practical implications to the product strategy of the film industry in China.
\end{abstract}

\section{Keywords}

Film Attractiveness, Audience Satisfaction, Mediating Effect, Motion Picture

\section{Introduction}

As one kind of product, films face specific audience in the end, but their investors, directors, producers and other participants of the production chain, seemingly concern more about the market. Hence, the movie box office research has been the research hotspot. Barry Litman concluded that box office (or rent) returns could be calculated in this equation: $\mathrm{Y}=-28.482 \times 10^{6}+7.232 \times 10^{6}$ Top Directors $+14.846 \times 10^{6}$ Stars $+11.818 \times 10^{6}$ Sci-Fi $+13.858 \times 10^{6}$ Sequels $+24.932 \times 10^{6}$ Oscar Nominations $-4.966 \times 10^{6}$ Plots $+6.972 \times 10^{6}$ Reviews + $3.814 \times 10^{6}$ Major Distribution Companies [1]. In the subsequent researches with Economic Methodology, other 
independent variables have been taken into consideration, i.e. Release Period, Scheduling, Market Concentration Rate [2], Grading [3] and Reputation [4] [5]. Over concerns and projections about the film's box office are likely to neglect the film attractiveness itself and the intrinsic motivation of the audience. For instance, some films are expected to have high box office revenues considering variables such as the stars, directors, scheduling, publicity, release and investment, while the reality is just the opposite. That means box office must be determined by some more front and secluded factors. By comparison, study with Communication Research Method focused more on the audience itself, e.g. investigations into individual's viewing habits and decision-making process, with which revealed some valuable factors. Learning and information, escapism, entertainment and relaxing, and friend-making are regarded as the main motivations [6] [7]. Moreover, research on the satisfaction of experience consumption provides insightful understand for the audience's cognitive [8], emotional [9] and other inner needs.

Though the study with Communication Research Method pays more attention on the audience than that with Economic Research Method does, it still fails to deeply understand the needs of the audience's mind and soul. Given the satisfaction researches have explored the inner need of the audience, there are many gaps in the study. As such, this paper attempts to establish an analytical framework for more insightful findings by adopting “film attractiveness”, a concept that blurs the borderline between Economics, Communication and Management. Literatures on this concept come from Tom Gunning and Gao Xueyi. But the former's “film attractiveness” is more about the type or expressing techniques of films [10], while the latter is not an empirical investigation based on the audience [11]. In this study, we defined film attractiveness as the capacity and possibility for films to attract viewers and satisfy their expectations. The viewers' reaction to a film is actually a comprehensive reflection of their feed forward, synchronic and feedback feelings, which is closely linked to their feelings.

According to the foregoing, the following research questions arise: What are the elements of the film attractiveness? Does the perception of film attractiveness affect the audience's outcome variable? How?

\section{Structure of the Film Attractiveness}

Given the limited space, we did not present the empirical process, but only main results. After item collection, pre-trial investigation and questionnaire revision, we formed a formal questionnaire with 55 questions. We asked respondents to evaluate the extent to which they agree or disagree with the statements on a six-point Likert-type scale ranging from (1) strongly disagree to (6) extremely agree to prevent response bias because Chinese people tend to choose the mid-point of the scale regardless of their true feelings or attitudes [12]. 1000 questionnaires were sent out and 733 valid ones were retrieved, yielding a response rate of $73.3 \%$. The interviewees: 1) Gender: males accounted for $47.3 \%$ and females 52.7\%; 2) Age: $13.4 \%$ were under the age of 20 , 23.7\% were between 21 to 30, 18.9\% were at the age of 31 to 40,35.7\% were between 41 to 50 and $8.3 \%$ were above 51; 3) Educational Background: 15.4\% were high school graduates, $27.0 \%$ were college students, $41.6 \%$ were undergraduates and $13.3 \%$ were postgraduates.

By conducting exploratory factor analysis, confirmatory factor analysis, test of reliability and validity, we extracted 5 factors (dimensions) of the film attractiveness, each one with 3 questions as shown in Table 1 . Results showed five distinct factors, accounting for $61.54 \%$ of the total variance with no single factor accounting for a majority of the variance. The 5 factors were named as Moral education, Plot, Satisfaction of curiosity, Entertainment and Reputation respectively as per questions included.

\section{The Effect of the Perception of Film Attractiveness on the Outcome Variables}

As seen in Table 1, the result manifests that film attractiveness is a comprehensive index based on multi factor, the utility of each factor has the mutual substitution or complementary effect. For different audience and even

Table 1. Question content and factor load $(\mathrm{N}=302)$.

\begin{tabular}{ccccccccccccccc}
\hline \multicolumn{2}{c}{ F1 Moral education } & F2 Plot & & F3 Satisfaction of curiosity & F4 Entertainment & F5 Reputation \\
\hline Mind purification & 0.864 & Unexpectedness & 0.773 & Sensitive topics & 0.809 & Emotional appeal & 0.719 & Friends’ praise & 0.719 \\
Mental harvest & 0.822 & Fascination & 0.754 & Truth revelation & 0.689 & Relaxation & 0.709 & Social debate & 0.683 \\
Inspiration & 0.791 & Logic & 0.725 & Information acquisition & 0.668 & Spiritual enjoyment & 0.667 & Representative & 0.680 \\
\hline
\end{tabular}


for the different life situations of the same audience, the utility value of each factor is relative and dynamic. Indeed, the film attractiveness is more reflected in a subjective feeling or evaluation. Thus we defined the subjective feelings and evaluation as the perception of film attractiveness.

We measured the perception of film attractiveness by asking respondents to evaluate the extent to which they agree or disagree with the15 statements (as shown at Table 1) on a six-point Likert-type scale. Given not mature scale of the audience satisfaction, intention and investment for reference, we developed these scales. 280 questionnaires were distributed, 237 copies were recovered with 196 valid copies. The interviewees: 1) Gender: 41.4\% are male and $58.6 \%$ are female; 2) Age: $18.1 \%$ are under the age of $20,53.4 \%$ are between 21 to $30,20.5 \%$ are between 31 to 40, 5.4\% are around 41 to 50 and another 2.6\% are above 51; 3) Educational Background: 3.2\% are high school graduates, $14.9 \%$ are college students, $48.5 \%$ are undergraduates and $33.1 \%$ are postgraduates.

As shown in Table 2, the values of Cronbach's $\alpha$ for all constructs were in excess of 0.70 , and the first principal components variance contribution rate near or above $60 \%$, indicating a high degree of reliability.

Satisfaction questionnaires: 1) I am very satisfied with the performance of most Chinese movies in two years. 2) Most Chinese movies meet my expectations, I feel very satisfied with this. 3) Compared with foreign movies, I am very satisfied with most of the Chinese movies I have seen. 4) Most of the Chinese film from the theme, the plot to the quality of production makes me satisfied. 5) As far as I know, my friends are very satisfied with most of the Chinese movies.

Intention questionnaires: 1) I would like to spend money, time and energy to watch Chinese movies. 2) Compared with foreign movies, I prefer to watch Chinese movies. 3) Most of the Chinese film from the theme, the story to the effect of audio and videos are all I like to enjoy.

Investment questionnaires: 1) The film I've seen in the past two years, Chinese films account for more than half. 2) I spend more money, time and energy on Chinese movies than foreign movies. 3) Watching most Chinese movies, I'm always immersed in the plot, the feelings of the movie plot and the changes and changes.

We then employed a confirmatory factor analysis (CFA) by AMOS7.0 to explore the affect of the perception of film attractiveness on the outcome variables, as shown by Figure 1. According to the model's correction index, bidirectional covariance relationship is established between the 8 residuals of the hypothesis model. The bidirectional covariance relationship has the reality basis, which indicates the correlation between the two items of the measurement content. The main fit index of the modified model is shown in Table 3.

In Figure 1, the standardized path coefficient of attractiveness perception F6 $\rightarrow$ satisfaction F7, attractiveness

Table 2. Reliability and validity of outcome variable scales $(\mathrm{N}=196)$.

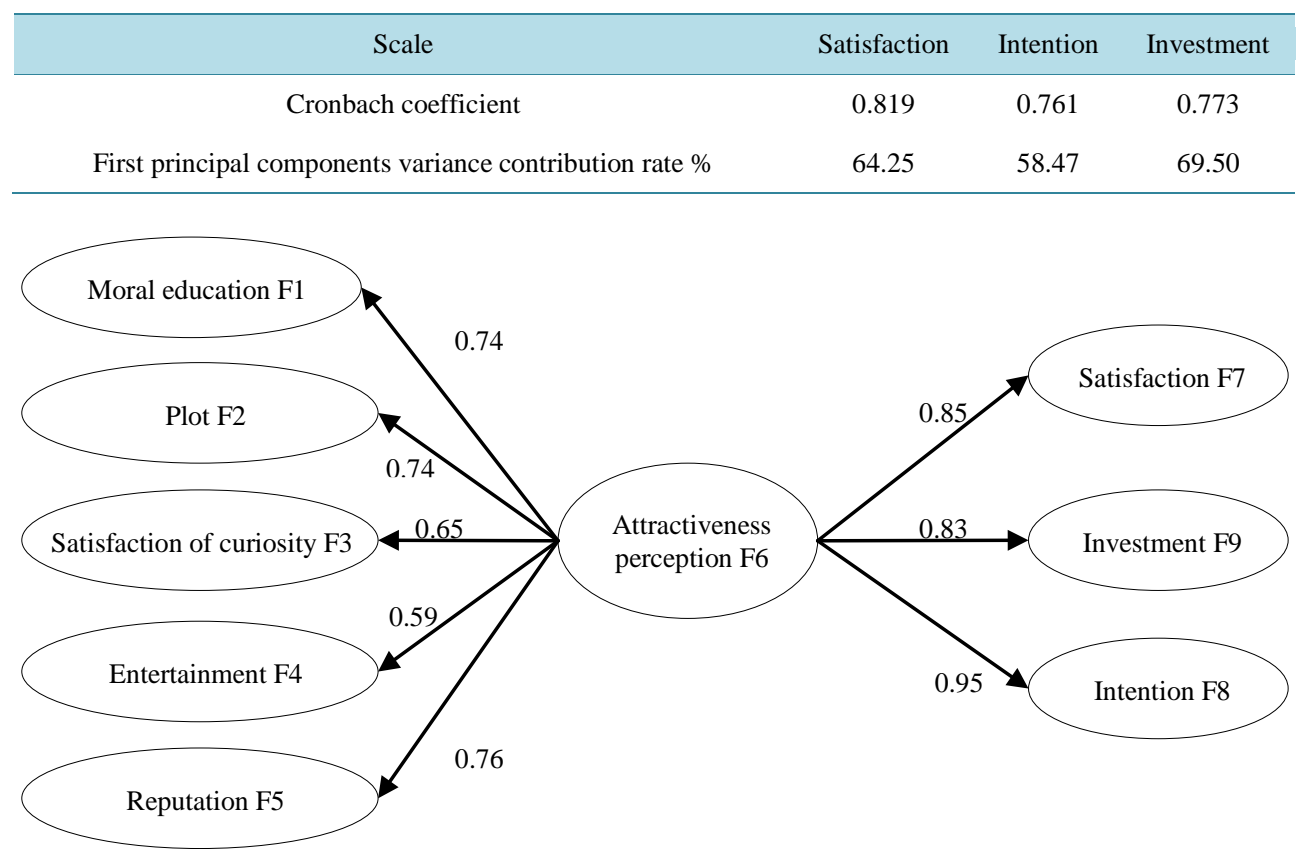

Figure 1. Model of relationship between attractiveness perception and its outcome variables. 
perception F6 $\rightarrow$ investment F8, attractiveness perception F6 $\rightarrow$ intention F9 were $0.85,0.83$ and 0.95 , all were significant. The results show the positive correlation relationship between the attractiveness perception and the satisfaction, intention, investment, respectively.

\section{Mediating Effect of Satisfaction}

\subsection{The Mediating Effect of Satisfaction between Attractiveness Perception and Intention}

According to the theory of consumer behavior, the mediating effect of consumer satisfaction in the commodity value perception and consumption intention is ubiquitous [13]. Film as one kind of special commodity, does audience satisfaction also play a mediating role between the attractiveness perception of the audience and the intention of viewing? We adopted the structural equation modelling (SEM) approach suggested by MacKinnon et al. [14] to build a mediation model, given that SEM helps to control for measurement errors and provides clearer and more comprehensive information on the degree of fit of the proposed models. Procedures and data are shown in Table 4. The results show that the audience satisfaction plays a fully mediating effect between the attractiveness perception and the intention of viewing.

\subsection{The Mediating Effect of Satisfaction between Attractiveness Perception and Investment}

Results in Table 5 show that the audience satisfaction plays a fully mediating effect between the attractiveness perception and the investment of viewing.

\section{Analysis on the Path of Film Attractiveness Effects on the Audience}

For further research the effect relationship among of the attractiveness perception, audience's satisfaction, intention and investment, we constructed the model F in Table 6. Our reasoning is, the attractiveness perception has

Table 3. Fit index of the modified model $(\mathrm{N}=196)$.

\begin{tabular}{cccccccccc}
\hline \multirow{2}{*}{ Fit index } & \multicolumn{3}{c}{ Absolute fit index } & \multicolumn{2}{c}{ Relative fit index } & \multicolumn{4}{c}{ Alternative index } \\
\cline { 2 - 10 } & CMIN & DF & CMIN/DF & NFI & PNFI & NCP & RMSEA & CFI \\
\hline & 474.840 & 312 & 1.522 & 0.771 & 0.686 & 162.840 & 0.060 & 0.906 \\
Optimal value & Minimum & - & $<2$ & $>0.9$ & $>0.5$ & Minimum & $<0.1$ & $>0.9$ \\
\hline
\end{tabular}

Table 4. Mediating effect of satisfaction between attractiveness perception and intention $(\mathrm{N}=196)$.

\begin{tabular}{|c|c|c|c|c|}
\hline Model & Path & $\begin{array}{c}\text { Standardized } \\
\text { path coefficient }\end{array}$ & $\begin{array}{l}\text { Significance } \\
\text { probability }\end{array}$ & Major fit index \\
\hline & $\mathrm{F} 6 \rightarrow \mathrm{F} 7$ & 0.735 & $* * *$ & $\begin{array}{l}\mathrm{CMIN}=236.909 ; \mathrm{CMIN} / \mathrm{DF}=1.462 ; \mathrm{NFI}=0.861 ; \mathrm{PNFI}=0.734 ; \\
\mathrm{NCP}=74.909 ; \mathrm{RMSEA}=0.049 ; \mathrm{CFI}=0.951\end{array}$ \\
\hline & $\mathrm{F} 6 \rightarrow \mathrm{F} 8$ & 0.742 & $* * *$ & $\begin{array}{l}\mathrm{CMIN}=189.389 ; \mathrm{CMIN} / \mathrm{DF}=1.306 ; \mathrm{NFI}=0.863 ; \mathrm{PNFI}=0.732 ; \\
\mathrm{NCP}=44.389 ; \mathrm{RMSEA}=0.040 ; \mathrm{CFI}=0.963\end{array}$ \\
\hline & $\mathrm{F} 7 \rightarrow \mathrm{F} 8$ & 0.878 & $* * *$ & $\begin{array}{l}\mathrm{CMIN}=28.538 ; \mathrm{CMIN} / \mathrm{DF}=1.142 ; \mathrm{NFI}=0.964 ; \mathrm{PNFI}=0.669 ; \\
\mathrm{NCP}=3.538 ; \mathrm{RMSEA}=0.027 ; \mathrm{CFI}=0.995\end{array}$ \\
\hline & $\mathrm{F} 6 \rightarrow \mathrm{F} 8$ & 0.224 & 0.056 & \\
\hline & $\mathrm{F} 6 \rightarrow \mathrm{F} 7$ & 0.731 & $* * *$ & $\begin{array}{l}\mathrm{CMIN}=336.806 ; \mathrm{CMIN} / \mathrm{DF}=1.392 ; \mathrm{NFI}=0.842 ; \mathrm{PNFI}=0.738 ; \\
\mathrm{NCP}=94.806 ; \mathrm{RMSEA}=0.045 ; \mathrm{CFI}=0.949\end{array}$ \\
\hline & $\mathrm{F} 7 \rightarrow \mathrm{F} 8$ & 0.716 & $* * *$ & \\
\hline & $\mathrm{F} 6 \rightarrow \mathrm{F} 7$ & 0.759 & $* * *$ & \\
\hline & $\mathrm{F} 7 \rightarrow \mathrm{F} 8$ & 0.898 & $* * *$ & $\begin{array}{l}\mathrm{CMIN}=340.410 ; \mathrm{CMIN} / \mathrm{DF}=1.401 ; \mathrm{NFI}=0.840 ; \mathrm{PNFI}=0.740 ; \\
\mathrm{NCP}=97.410 ; \mathrm{RMSEA}=0.045 ; \mathrm{CFI}=0.947\end{array}$ \\
\hline
\end{tabular}

Note: ${ }^{*} p<0.05 ;{ }^{* * *} p<0.001$, similar hereinafter. 
Table 5. Mediating effect of satisfaction between attractiveness perception and investment $(\mathrm{N}=196)$.

\begin{tabular}{|c|c|c|c|c|}
\hline Model & Path & $\begin{array}{l}\text { Standardized } \\
\text { path coefficient }\end{array}$ & $\begin{array}{l}\text { Significance } \\
\text { probability }\end{array}$ & Major fit index \\
\hline & F6 $\rightarrow$ F7 & 0.735 & $* * *$ & $\begin{array}{l}\mathrm{CMIN}=236.909 ; \mathrm{CMIN} / \mathrm{DF}=1.462 ; \mathrm{NFI}=0.861 ; \mathrm{PNFI}=0.734 ; \\
\mathrm{NCP}=74.909 ; \mathrm{RMSEA}=0.049 ; \mathrm{CFI}=0.951 ;\end{array}$ \\
\hline & F6 $\rightarrow$ F9 & 0.670 & $* * *$ & $\begin{array}{l}\mathrm{CMIN}=214.568 ; \mathrm{CMIN} / \mathrm{DF}=1.676 ; \mathrm{NFI}=0.846 ; \mathrm{PNFI}=0.708 ; \\
\mathrm{NCP}=86.568 ; \mathrm{RMSEA}=0.059 ; \mathrm{CFI}=0.930 ;\end{array}$ \\
\hline & F7 $\rightarrow$ F9 & 0.793 & $* * *$ & $\begin{array}{l}\text { CMIN = 31.397; CMIN/DF = 1.962; NFI = 0.960; PNFI = 0.549; } \\
\text { NCP = 15.397; RMSEA = 0.070; CFI = 0.980; }\end{array}$ \\
\hline & $\mathrm{F} 6 \rightarrow \mathrm{F} 9$ & 0.199 & 0.104 & \\
\hline & $\mathrm{F} 6 \rightarrow \mathrm{F} 7$ & 0.721 & $* * *$ & $\begin{array}{l}\mathrm{CMIN}=370.18 ; \mathrm{CMIN} / \mathrm{DF}=1.690 ; \mathrm{NFI}=0.827 ; \mathrm{PNFI}=0.716 ; \\
\mathrm{NCP}=151.108 ; \mathrm{RMSEA}=0.059 ; \mathrm{CFI}=0.920\end{array}$ \\
\hline & $\mathrm{F} 7 \rightarrow \mathrm{F} 9$ & 0.735 & *** & \\
\hline & F6 $\rightarrow$ F7 & 0.754 & $* * *$ & \\
\hline & $\mathrm{F} 7 \rightarrow \mathrm{F} 9$ & 0.803 & $* * *$ & $\begin{array}{l}\mathrm{CMIN}=379.484 ; \mathrm{CMIN} / \mathrm{DF}=1.717 ; \mathrm{NFI}=0.823 ; \mathrm{PNFI}=0.719 ; \\
\mathrm{NCP}=158.484 ; \mathrm{RMSEA}=0.061 ; \mathrm{CFI}=0.916 ;\end{array}$ \\
\hline
\end{tabular}

Table 6. The relationship among attractiveness perception and the outcome variables $(\mathrm{N}=196)$.

\begin{tabular}{|c|c|c|c|c|}
\hline Model & Path & $\begin{array}{c}\text { Standardized } \\
\text { path coefficient }\end{array}$ & $\begin{array}{l}\text { Significance } \\
\text { probability }\end{array}$ & Major fit index \\
\hline \multirow{10}{*}{$\mathrm{F}$} & $\mathrm{F} 6 \rightarrow \mathrm{F} 7$ & 0.732 & $* * *$ & \multirow{6}{*}{$\begin{array}{l}\mathrm{CMIN}=460.451 ; \mathrm{CMIN} / \mathrm{DF}=1.495 ; \mathrm{NFI}=0.825 \\
\mathrm{PNFI}=0.724 ; \mathrm{NCP}=152.451 ; \mathrm{RMSEA}=0.050 \\
\mathrm{CFI}=0.933 ;\end{array}$} \\
\hline & $\mathrm{F} 6 \rightarrow \mathrm{F} 8$ & 0.239 & 0.039 & \\
\hline & $\mathrm{F} 6 \rightarrow \mathrm{F} 9$ & 0.032 & 0.793 & \\
\hline & $\mathrm{F} 7 \rightarrow \mathrm{F} 8$ & 0.711 & $* * *$ & \\
\hline & $\mathrm{F} 7 \rightarrow \mathrm{F} 9$ & -0.035 & 0.876 & \\
\hline & $\mathrm{F} 8 \rightarrow \mathrm{F} 9$ & 0.861 & 0.002 & \\
\hline & $\mathrm{F} 6 \rightarrow \mathrm{F} 7$ & 0.732 & $* * *$ & \multirow{4}{*}{$\begin{array}{l}\mathrm{CMIN}=460.550 ; \mathrm{CMIN} / \mathrm{DF}=1.486 ; \mathrm{NFI}=0.825 \\
\mathrm{PNFI}=0.728 ; \mathrm{NCP}=150.550 ; \mathrm{RMSEA}=0.050 ; \\
\mathrm{CFI}=0.934 ;\end{array}$} \\
\hline & $\mathrm{F} 6 \rightarrow \mathrm{F} 8$ & 0.251 & 0.022 & \\
\hline & $\mathrm{F} 7 \rightarrow \mathrm{F} 8$ & 0.700 & $* * *$ & \\
\hline & $\mathrm{F} 8 \rightarrow \mathrm{F} 9$ & 0.854 & $* * *$ & \\
\hline
\end{tabular}

both direct and indirect effects on intention, and the indirect effect is mediated by the satisfaction. Similarly, the attractiveness perception has both direct and indirect effects on investment, and the indirect effect is mediated by the satisfaction. Referring to motivation theory [15], the motivation is the premise of the behavior. Specifically, intention of viewing is the antecedent condition of investment, namely, intention of viewing has direct impact on investment of viewing.

Running AMOS7.0 on the model F, the results are shown in the Table 6. According to the significant probability P value, we deleted F6 $\rightarrow$ F9, F7 $\rightarrow$ F9 two paths that their probability P value are not significant at 0.05 level and thus set up a correction model (model G). Running AMOS7.0 on the model G, fit index shows that the final model can be accepted.

Figure 2 is an enlarged graph of the model G. By graph, at 0.001 level of significant probability, attractiveness perception effects intention via audience's satisfaction, and intention effects investment. At 0.1 level of significant probability, audience satisfaction plays a fully mediating effect between attractiveness perception and intention. 


\section{Analysis on the Attraction Factor for Predicting Audience Satisfaction}

In views of the foregoing, audience satisfaction is an important variable, for it not only completely mediate attractiveness perception and investment, but also has a complete mediation effect between attractiveness perception and intention. Attractiveness perception affects the final behavior of the audience through the path of audience satisfaction $\rightarrow$ viewing intention $\rightarrow$ investment (Figure 2). Therefore, it is necessary to analyze among the 15 factors in the structure of the film attractiveness, to find out which ones have a predictive power on the audience's satisfaction, so as to guide the film enterprises, producers, directors, etc. to use these factors to improve the audience satisfaction, to attract the audience, to increase the audience's intention and investment.

Conducting the stepwise multiple regression analysis, we regressed the 15 attractiveness factors on satisfaction. As shown in Table 7, Friends' praise, Mind purification, Logic, Inspiration have significant predictive power for audience satisfaction. The multivariate correlation coefficient between the 4 predictor variables and the audience satisfaction was 0.654 , which can explain the variation of audience satisfaction 42.8\%; Friends' praise has the most predictive power, it explain the variation of audience satisfaction $25.5 \%$, and then Mind purification 11.9\%, Logic 3.8\%, Inspiration 1.6\%. Standardized regression equation is: Audience satisfaction $=$ $0.330 \times$ Friends' praise $+0.217 \times$ Mind purification $+0.206 \times$ Logic $+0.157 \times$ Inspiration .

Standardized regression equation shows that, if a film of logical plot can make the audience hear friends' praise before viewing, their mind are purified spirit are stimulated in the process of or after viewing, then it can be predicted that the audience will be more satisfied with it. Given the reason of friends’ praise might be the result of Mind purification, Logic, Inspiration, to rule out circular argument, the safer conclusion is that Mind purification, Logic and Inspiration are the main factors regarding the audience satisfaction. Mind purification and Inspiration come from Moral Education dimension (see Table 1), this shows the audience does not exclude the film's education function, on the contrary, the film that can really purify soul and incentive morale has an important role in improving the audience satisfaction. This also indicates that whether the audience satisfies with a movie, more is determined by the feeling deep inside the heart and soul, the role of external effect is relatively limited. Logic comes from Plot dimension, this factor selected by the Stepwise Multiple Regression, shows that not only the audience pay attention to the film's spiritual experience, but also to the science and rationality of film's story. It can be said that the audience see the film with heart and brain, to really improve their satisfaction, a film must satisfy them emotionally and also rationally.

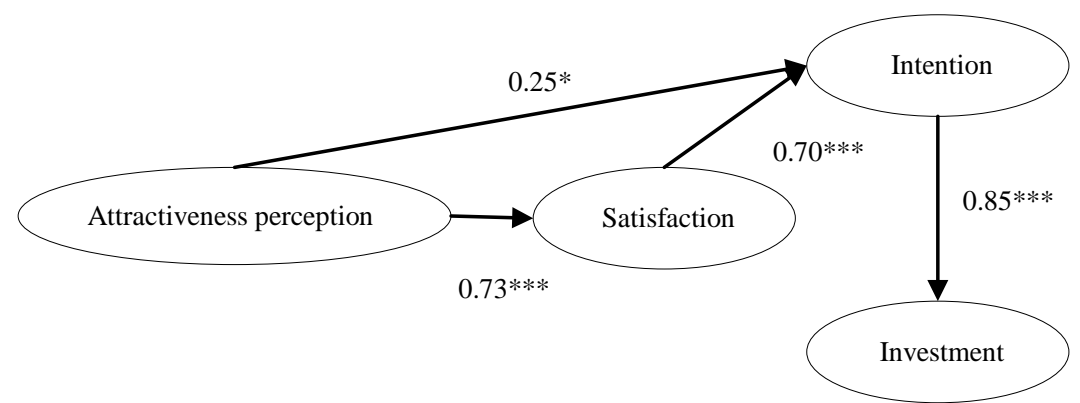

Figure 2. The relationship among attractiveness perception and the outcome variables.

Table 7. Summary of stepwise multiple regression of the 15 attractiveness factors on satisfaction $(\mathrm{N}=196)$.

\begin{tabular}{ccccccc} 
Model & $\mathrm{R}$ & $\mathrm{R}^{2}$ & $\Delta \mathrm{R}^{2}$ & $\mathrm{~F}$ & $\Delta \mathrm{F}$ & $\beta$ \\
\hline 1. Friends' praise & 0.505 & 0.255 & 0.255 & $66.535^{* * *}$ & $66.535^{* * *}$ & 0.330 \\
2. Mind purification & 0.612 & 0.374 & 0.119 & $57.754^{* * *}$ & $36.722^{* * *}$ & 0.217 \\
3. Logic & 0.642 & 0.412 & 0.038 & $44.850^{* * *}$ & $12.287^{* * *}$ & 0.206 \\
4. Inspiration & 0.654 & 0.428 & 0.016 & $35.745^{* * *}$ & $5.368^{*}$ & 0.157 \\
\hline
\end{tabular}




\section{Conclusion and Suggestion}

The Chinese film attractiveness is comprised of five dimensions; according to the priority sequence, they are plot, entertainment, moral education, satisfaction of curiosity and reputation. Chinese films can improve their attraction through these 5 aspects. Audience satisfaction plays a fully mediating effect between the attractiveness perception and the investment of viewing. Audience satisfaction also plays a fully mediating effect between the attractiveness perception and the intention of viewing. Film attractiveness affects the final behavior of the audience through this path: perception of film attractiveness $\rightarrow$ satisfaction $\rightarrow$ intention $\rightarrow$ investment. Mind purification, logic and inspiration are the main factors to improve the audience satisfaction.

\section{References}

[1] Litman, B. (1989) Predicting Success of Theatrical Movies: The 80’s Experience. Journal of Media Economics, 2, 3550. http://dx.doi.org/10.1080/08997768909358184

[2] Sochay, S. (1994) Predicting the Performance of Motion Pictures. Journal of Media Economics, 4, 1-21. http://dx.doi.org/10.1207/s15327736me0704 1

[3] Sawhney, M. and Eliashberg, J. (1996) A Parsimonious Model for Forecasting Gross Box-Office Revenues of Motion Pictures. Marketing Science, 2, 113-131. http://dx.doi.org/10.1287/mksc.15.2.113

[4] Hennig, T., et al. (2006) The Differing Roles of Success Drivers across Sequential Channels: An Application to the Motion Picture Industry. Journal of the Academy of Marketing Science, 4, 559-575. http://dx.doi.org/10.1177/0092070306286935

[5] Liu, Y. (2006) Word of Mouth for Movies: Its Dynamics and Impact on Box Office Revenue. Journal of Marketing, 3 , 74-89. http://dx.doi.org/10.1509/jmkg.70.3.74

[6] Möller, K. and Karppinen, P. (1983) Role of Motives and Attributes in Consumer Motion Picture Choice. Journal of Economic Psychology, 3, 239-262. http://dx.doi.org/10.1016/0167-4870(83)90029-6

[7] Gazley, A., Clark, G. and Sinha, A. (2011) Understanding Preferences for Motion Pictures. Journal of Business Research, 8, 854-861. http://dx.doi.org/10.1016/j.jbusres.2010.09.012

[8] Ladhari, R. (2007) The Movie Experience: A Revised Approach to Determinants of Satisfaction. Journal of Business Research, 5, 454-462. http://dx.doi.org/10.1016/j.jbusres.2006.12.007

[9] Ladhari, R. (2007) The Effect of Consumption Emotions on Satisfaction and Word-of-Mouth Communications. Psychology \& Marketing, 12, 1085-1108. http://dx.doi.org/10.1002/mar.20195

[10] Tom, G. (1986) The Cinema of Attractions: Early Cinema, Its Spectator, and the Avant-Garde. Wide Angle, 8, 3-4.

[11] Gao, X.Y. (2009) On the Structure of Film Attractiveness. Art of Huangmei Opera, 2, 66-67.

[12] Cheung, P. (2012) China's Changing Regional Development: Trends, Strategies and Challenges in the 12th Five-Year Plan (2011-2015) Period. Asia Pacific Viewpoint, 1, 1-6. http://dx.doi.org/10.1111/j.1467-8373.2012.01471.x

[13] Wei, W.Z. and Chen, M.Y. (2010) Research on Retail Brand Image and Customer Satisfaction and Loyalty. Commercial Research, 9, 137-140.

[14] Mackinnon, D., et al. (2002) A Comparison of Methods to Test Mediation and Other Intervening Variable Effects. Psychological Methods, 1, 83-104. http://dx.doi.org/10.1037/1082-989X.7.1.83

[15] Kae, H. (1969) Toward a General Theory of Motivation and Performance. California Management Review, 3, 81-88. 